\title{
УДК: 378.14
}

\section{ДОСЯГНЕННЯ ЯК ОДИН 3 ЧИННИКІВ МОТИВАЦІЇ СТУДЕНТІВ ВИЩИХ НАВЧАЛЬНИХ ЗАКЛАДІВ}

\author{
(C) Б. С. Коломієць
}

Проаналізувавши проблеми самоосвіти на сучасному етапі, стало можливим звузити кількість чинників, котрі впливають на мотиваџійну сферу студента. Визначено взаємозалежність «досягнення» та комунікативних здібностей, необхідних для подачі відповідної інформачії викладачем. Окреслено основні завдання для проведення успішної самоосвітньої діяльності студентів. Визначено роль колективу у процесі здобуття знань та необхідні при ичьоу види роботи

Ключові слова: самоосвіта, мотивачійна сфера, комунікативні здібності, досягнення , колективна діяльність, робота з інформацією

Analyzing the problems of self-education at the modern stage, it became possible to diminish the number of
factors that influence students' motivation. There was defined interdependence between the notion
"achievement" and communicative possibilities of teacher, necessary for presentation of correspondent
information. There is a possibility to raise the internal motivation of students by presentation of the certain
possible profit that will be achieved in the process of learning. Self-education is carried out by teachers or tutors
who have to learn during whole the life because of continuously growing amount of information for successful
exams passage by students. There was elucidated the process of transforming information into knowledge and
the value of knowledge as one of sources of gaining profit Keywords: self-education, motivation sphere, communicative abilities, achievement, collective activity, work with information

\section{1. Вступ}

У наш час зростає значення педагогічної майстерності викладача, його готовність керувати процесом підготовки майбутніх спеціалістів та здатність до підвищення власної кваліфікації впродовж усього професійного життя, що є ключовим елементом розвитку професіоналізму та веде до постійного удосконалення методів та прийомів проведення аудиторних занять. Слід визначити чинники, що впливають на мотиви, та спонукають викладачів до процесу безперервного самостійного здобуття знань самоосвіти.

Можливі досягнення за допомогою постійної самоосвіти:

1. Шляхом освіти впродовж життя, людина постійно розвиває всі здобуті під час навчання знання, вміння, навички, власні здібності, підвищує свій професійний рівень, поповнює практичний досвід, намагається встигати за всіма змінами в суспільстві, швидко пристосовується до нових вимог, які постають перед нею, і зрештою, отримує високий рівень професійної компетентності.

2. Навчання впродовж життя стало ключовим елементом у визначенні Свропейським Союзом стратегій, щодо завдання формування найдинамічнішого і конкурентноспроможного суспільства, яке базується на знаннях. Тобто даний вид освіти, дасть змогу майбутнім спеціалістам бути конкурентноспроможними на ринку праці та прогнозувати майбутні тенденції розвитку того чи іншого напряму діяльності, базуючись на розумінні стратегій та завдань СС.

\section{2. Аналіз джерел і публікацій}

Визначення поняття самоосвіта освітлюється 3 різних сторін, так М. М. Заборщикова, В. В. Новічков, П. Г. Пшебильський [1] вважають ії цілеспрямо- ваною плановою самостійною роботою вчителя 3 метою підвищення своєї майстерності. Процесом цілеспрямованого та систематичного поліпшення, вдосконалення, розвитку себе та своєї діяльності вважає Н. В. Козієв [1]. Процесом саморозвитку, що передбачає і й самопізнання називають самоосвіту Ю. М. Кулюткін, Г. С. Сухобська [1]. Іншою точкою зору є визначення самоосвіти як видом пізнавальної діяльності, що характеризується добровільністю та самостійністю (Л. Г. Борисова, Г. Б. Бичкова) [2].

Тож, поняття «самоосвіта» не має чіткого визначення, не досліджено зв'язки 3 поняттям «досягнення» та впливом мотивації.

\section{3. Мета та задачі дослідження}

Метою даної статті є висвітлення мотиваційної сфери особистості через призму самоосвіти.

Для досягнення поставленої мети були вирішені наступні задачі: визначено існуючі поняття терміну «самоосвіта», чинники що впливають на мотиваційну сферу особистості через ії намагання задовольнити власну потребу у досягненні.

\section{4. Навчання впродовж життя}

Так у меморандумі Сврокомісії 2000 року зазначено, що пріоритетні напрями розвитку навчання впродовж життя та мету кожного 3 них необхідно враховувати при створенні нових моделей підвищення кваліфікації спеціалістів різних напрямів [3]. Це означає що, всі новітні інноваційні методики підвищення кваліфікації мають містити шляхи та вказівки процесу самоосвіти та, можливо, приховані або явні мотиви до здійснення даного виду діяльності.

Викладач сучасного навчального закладу має за будь-яких умов намагатися виконувати свій обов'язок і професійну місію: розвиватися самому 
тим самим забезпечуючи можливості для розвитку інших, а саме - студентів, що є майже неможливим за умови відмови викладача від самоосвіти.

Навчальний процес у вищих навчальних закладах організований, як колективна діяльність. Він спрямований на те, щоб навчити студентів розуміти загальні завдання навчання, організовано працювати, допомагати один-одному, формувати відчуття колективізму, що зумовлює ситуацію конкуренції в межах певної навчальної групи.

В основі традиційної системи навчального процесу лежить схема: «знання-вміння-навичкимайстерність», де головним фактором є знання, інформація, вміння, яких студенти набувають за допомогою педагога та від педагога. Як свідчать практика i дослідження таке навчання є малоефективним. Проте, головним педагогічним завданням на першому етапі «знання» $є$ забезпечення студентів умінням перетворювати інформацію на знання та використовувати їх на практиці. Основною метою, на початковому етапі, у викладача $є$ роз'яснення чіткої та логічної послідовності даної системи [4]. Тобто, лише знання можуть бути переведені на наступний рівень «вміння», що в свою чергу за певної кількості практики перетворюються на «навички» і т. д.

Іншою частиною підтримки навчального процесу викладачем є забезпечення студентства чіткою метою, завданням навчання та прогнозування можливих наслідків їх ефективної, малоефективної, неефективної діяльності разом 3 ймовірними результатами [5]. Слід пояснити студентам навіщо вони навчаються, чому, та що, в результаті навчання вони зможуть отримати. На даному етапі є можливість мотивувати студентів майбутніми результатами їх навчальної роботи, такими як, рівень професіоналізму, конкурентоспроможності на ринку праці, ймовірний заробіток у тій чи іншій сфері тощо.

Джерелом прибутку виступають знання, інновації, технології та способи їх практичної реалізації, інформація стає стратегічним ресурсом не тільки особистості-студента а й цілої країни. Разом з рівнем розвитку, освіта багато в чому визначає суверенітет та економічну незалежність, інтелектуальний рівень населення тощо.

Сучасний етап розвитку освіти в Україні характеризується відмовою від тотальної уніфікації і стандартизації педагогічного процесу, інтенсивним переосмислення цінностей, пошуками нового. Інтенсивне реформування освіти вимагає наполегливих пошуків трансформування освітнього процесу на гуманістичних засадах, що передбачає зміни у процесі отримання знань [6].

Серед багатьох видів методів активного навчання на заняттях із дисциплін гуманітарного циклу, особлива увага приділяється ігровим технологіям, покликаним активізувати процес навчання і наблизити його до реальної професійної діяльності, адже використання гри в навчальному процесі - це допомога в самовдосконаленні, подоланні внутрішнього конфлікту, стимулюванні піднесеного настрою, активній мобілізації [7]. Тому його включення (при відсутності) або активне використання вважається доцільним.
Проте це не означає що даний метод активного навчання має займати домінантні позиції у процесі здобуття знань.

Більшість сучасних студентів віддають перевагу інформації, що подається у спрощеному вигляді, це передбачає отримання знань не докладаючи належних психічних зусиль. Тому слід визначити етапи та порядок перетворення поданої інформації на знання, на прикладі самостійної роботи з науковою літературою. Основою будь-якого пізнання є робота з інформацією, а процес перетворення інформації на знання засновується на умінні аналізу наукових джерел та має включати наступні етапи:

- загальне ознайомлення 3 вирішенням наукової проблеми;

- перегляд відібраної літератури та іiі систематизації відповідно до змісту роботи та черговості іiі вивчення;

- читання за послідовністю розміщення матеріалу;

- вибіркове читання окремих частин;

- виписування потрібного матеріалу;

- критичне оцінювання записаного, редагування і чистовий запис у вигляді фрагменту тексту наукової роботи;

- осмислення та усвідомлення цінності написаного та шляхів практичного використання [8].

Даний перелік передбачає високу внутрішню мотивацію студентів до виконання даного виду завдань. При недостатній мотивації, певний студент може не дійти до останнього пункту списку. Що ж впливає на мотиви особистості?

Системне представлення мотиваційної сфери людини дозволяє дослідникам класифікувати мотиви. У загальній психології види мотивації, діяльності розмежовується за різними підставами, наприклад залежно від:

- характеру участі в діяльності;

- часу зумовлювання діяльності;

- соціальної значущості;

- факту включення в саму діяльність. [Мотиви навчальної діяльності (за Марковою А. К.)] [9].

До визначення домінуючої мотивації діяльності доцільно також підійти з позиції особливостей інтелектуально-емоційно-вольової сфери самої особи як суб'єкта. Відповідно, вищі духовні потреби людини можуть бути представлені, як мотиви морального, інтелектуально-пізнавального та естетичного планів. Вищі соціальні духовні мотиви умовно можуть бути розділені на три групи:

I. Інтелектуально-пізнавальні.

II. Морально-етичні.

III. Емоиійно-естетичні.

Навчальна мотивація визначається:

- самою освітньою системною, установою;

- організацією освітнього процесу;

- суб' єктними особливостями педагога;

- відношенням педагога до навчання;

- специфікою навчальної дисципліни;

• рівнем зацікавленості об'єкта навчання.

Найважливішою передумовою створення інтересу до вивчення дисципліни $є$ виховання широких 
соціальних мотивів діяльності, розуміння іiі сенсу, змісту навчання, як частини власної майбутньої діяльності та професійної компетентності.

Основний засіб виховання стійкого інтересу до навчання $-\epsilon$ використання таких запитань і завдань, вирішення яких вимагає від студентів активної пошукової діяльності, що пов'язана безпосередньо з їх майбутньою професією.

Найбільший вплив (з соціологічних чинників) має потреба в досягненні, під якою розуміється прагнення людини до поліпшення своєї діяльності. Задоволеність навчанням напряму залежить від ступеня задоволеності цієї проблеми. Тобто, задовольнити внутрішні і зовнішні потреби в навчанні можливо лише задовольнивши потреби в досягненні. При чому, маючи соціальну або наукову значущість, дане досягнення має позитивно вплинути на внутрішній мотиваційний стан особистості. Досягнення, як мета, має бути відповідно подане викладачем для підвищення рівня зацікавленості студентства у його здобутті.

За допомогою вербального повідомлення можливо зацікавити майбутніх професіоналів, мотивувати їх до досягнення мети навчання, представити досягнення у найкращому світлі. Це все представляє комунікативну сторону спілкування, що проявляється через дії особистості, свідомо орієнтовані на їхнє особисте сприйняття іншими людьми. У комунікативному процесі відбувається не лише обмін інформацією, а й один з етапів перетворення іiї на знання. Майбутня особистість фахівця, науковця, залежить від вміння спілкуватися в професійному середовищі.

Практика підтверджує, що педагог має пристосовувати свої повідомлення до рівня аудиторії, вміло формулювати та формувати думку, добирати слова, будувати речення тощо [10].

Викладачі професій що належать до типу «людина-людина», тобто професіоналізм фахівця залежить, насамперед, від комунікативних якостей, стилю спілкування, сили впливу на поведінку інших людей та інтегральної чутливості до об’єкта, процесу та результату професійної діяльності, мають змогу зацікавити студента непрофільної спеціальності, наприклад «лікар», до оволодіння комунікативними навичками. Тож маємо можливість визначити взаємозалежність уміння викладача зацікавити до виконання певного виду завдань та здатністю демонструвати належний рівень комунікативних здібностей.

Формування професійного мовлення у майбутнього фахівця здебільшого відбувається за рахунок спілкування 3 викладачами і роботи 3 літературою, та включає в себе усвідомлення наступних частин:

1. Професійне спілкування - передумова успішної діяльності.

2. Значимість комунікативної складової підготовки фахівця у контексті уміння доносити необхідну інформацію.

3. Комунікативна компетенція - це необхідний компонент самореалізації та самовдосконалення особистості.

Тож, можливо, слід використовувати особистісну модель навчання, мета якої дати студентам цілісну картину дисципліни на основі науки і літератури 3 урахуванням 2-х основних ліній психічного розвитку особистості:

1. Пізнавальна мотивація.

2. Активність мислення.

За умови проходження студентами усіх необхідних етапів з урахуванням спеціально організованої педагогом орієнтувальної основи дії, можна гарантувати сформованість знань і умінь із заздалегідь заданими якостями [11].

\section{6. Результати дослідження}

В результаті проведених досліджень стало можливо визначити взаємозалежність понять «самоосвіта» та «досягнення», що прослідковувалася шляхом визначення мотиваційних чинників особистості. Було виявлено шляхи та засоби роботи з інформацією, як одного зі способів самоосвіти, так як лише перетворення інформації на знання і є самоосвітою. Суб'єктом навчання постає особа, тож самоосвіта являє собою підсвідомий перманентний процес 3 чого випливає основна задача, для дослідників самоосвіти як явища, переведення даного процесу з підсвідомого на свідомий рівень.

\section{7. Висновки}

Найгостріші проблеми сучасного навчального процесу пов'язані $з$ демотивованістю основної маси студентів, що призводить до зниження базових показників їх навчання. На даному етапі слід мотивувати студентів засобом «досягнення». Проте, це можливо лише за умови значущості, значимості самого досягнення, не лише на думку студента, одногрупників, викладачів, а й системи в цілому. Способами розвитку підвищення мотивації $є$ залучення студентів до науково-дослідної роботи, самостійної діяльності в процесі навчання.

Самоконтроль, самооцінювання, зіставлення власних досягнень із досягненнями інших студентів групи навчають плануванню своїх дій, відповідальності за той чи інший крок, та в деякій мірі управлінню власним навчальним процесом. Навчання спрямоване на досягнення сприяє усвідомленню студентами важливості знань для успішного оволодіння професією.

\section{Література}

1. Сидорчук, Н. Г. Категорійний аналіз поняття «Самоосвітня діяльність майбутнього вчителя» [Текст] / Н. Г. Сидорчук // Вісник Житомирського педагогічного університету. - 1999. - Вип. 3. - С. 59-63.

2. Беляєва, О. М. Освітні інновації: сутність, структура, функції суб'єкти [Текст]: матер. наук.-практ. конф. / О. М. Бєляєва // Удосконалення якості підготовки лікарів у сучасних умовах, 2016. - С. 19-20.

3. Алексєнко, Т. Ф. Біла книга національної освіти України [Текст] / Т. Ф. Алексєнко, В. М. Аніщенко, Г. О. Балл та ін.; за заг. ред. В. Г. Кременя. - К.: ТОВ «Інформаційні системи», 2010. - 342 с.

4. Бойко, В. В. Аналіз основних пріоритетів в розвитку навчання впродовж всього життя [Текст]: зб. наук. пр. / В. В. Бойко // Проблеми сучасної педагогічної освіти: педагогіка і психологія. - 2008. - № 19, Ч. 3.

5. Амонашвілі, Ш. А. Личностно-гуманная основа педагогического процесса [Текст] / Ш. А. Амонашвілі. Мн., 1990. -560 c. 
6. Безшапочний, С. Б. Удосконалення освітніх технологій на кафедрі оториноларингології 3 майбутніми медичними працівниками середньої освіти [Текст]: матеріали наук.-практ. конф. / С. Б. Безшапочний, Н. Б. Соннік, В. В. Лобурець // Удосконалення якості підготовки лікарів у сучасних умовах, 2016. - С. 16-17.

7. Баштан, В. П. Інноваційні технології навчання, як засіб удосконалення якості підготовки лікарів [Текст]: матер. наук.-практ. конф. / В. П. Баштан, О. В. Корнєва, А. В. Чорнобай, П. В. Шелешко, В. Є. Литвиненко, О. Є. Муковоз // Удосконалення якості підготовки лікарів у сучасних умовах, 2016. - C. 12-13.

8. Бєлікова, I. В. Формування навичок комунікації та роботи з інформацією в студентів-медиків [Текст]: матер. наук.-практ. конф. / І. В. Бєлікова, А. В. Кострікова, Н. О. Ляхова // Удосконалення якості підготовки лікарів у сучасних умовах, 2016. - С. 18-19.

9. Маркова, А. К. Формирование мотивации учения в школьном возрасте [Текст]: пособие для учителя / А. К. Маркова. - М.: Просвещение, 1983. - 96 с.

10. Буряк, В. Є. Умови та засоби самоосвіти студетів. Т. 6 [Текст] / В. С. Буряк. - Київ: Вища школа, 2002. - C. $18-28$.

11. Подольська, Є. А. Освітня послуга : проблеми якості вищої освіти [Текст] / Є. А. Подольська // Вчені записки Харківського гуманітарного університету «Народна Українська академія». - 2010. - Т. 16. - С. 130-134.

\section{References}

1. Sydorchuk, N. G. (1999). Kategorijnyj analiz ponyattya «Samoosvitnya diyal'nist' majbutn'ogo vchytelya». Visnyk Zhytomyrs'kogo pedagogichnogo universytetu, 3, 59-63.
2. Belyaeva, O. M. (2016). Osvitni innovacii': sutnist', struktura, funkcii' sub'ekty. Udoskonalennya yakosti pidgotovky likariv u suchasnyh umovah, 19-20.

3. Aleksenko, T. F., Anishhenko, V. M., Ball, G. O. et. al.; Kremen, V. G. (Ed.) (2010). Bila knyga nacional'noi' osvity Ukrai'ny. Kyiv: TOV «Informacijni systemy», 342.

4. Bojko, V. V. (2008). Analiz osnovnyh priorytetiv v rozvytku navchannya vprodovzh vs'ogo zhyttya. Problemy suchasnoi' pedagogichnoi' osvity: pedagogika i psyhologiya, 19, part 3 .

5. Amonashvili, Sh. A. (1990). Lichnostno-gumannaya osnova pedagogicheskogo processa. Mn., 560.

6. Bezshapochnyj, S. B., Sonnik, N. B., Loburec', V. V. (2016). Udoskonalennya osvitnih tehnologij na kafedri otorynolaryngologii' Z majbutnimy medychnymy pracivnykamy seredn'oi' osvity. Udoskonalennya yakosti pidgotovky likariv u suchasnyh umovah, 16-17.

7. Bashtan, V. P., Korneva, O. V., Chornobaj, A. V., Sheleshko, P. V., Lytvynenko, V. E., Mukovoz, O. E. (2016). Innovacijni tehnologii' navchannya, yak zasib udoskonalennya yakosti pidgotovky likariv. Udoskonalennya yakosti pidgotovky likariv u suchasnyh umovah, 12-13.

8. Belikova, I. V., Kostrikova, A. V., Lyahova, N. O. (2016). Formuvannya navychok komunikacii' ta roboty $\mathrm{z}$ informacieyu $\mathrm{v}$ studentiv-medykiv. Udoskonalennya yakosti pidgotovky likariv u suchasnyh umovah, 18-19.

9. Markova, A. K. (1983). Formirovanie motivacii ucheniya v shkol'nom vozraste. Moscow: Prosveshhenie, 96.

10. Buryak, V. E. (2002). Umovy ta zasoby samoosvity studetiv. Vol. 6. Kyiv: Vyshha shkola, 18-28.

11. Podol's'ka, E. A. (2010). Osvitnya posluga : problemy yakosti vyshhoi' osvityю Vcheni zapysky Harkivs'kogo gumanitarnogo universytetu «Narodna Ukrai'ns'ka akademiya», 16, 130-134.

Рекомендовано до публікації д-р пед. наук, професор Олійник В. В. Дата надходження рукопису 17.05.2016

Коломісць Богдан Сергійович, аспірант, кафедра педагогіки психології та філософії, Кременчуцький національний університет імені Михайла Остроградського, вул. Першотравнева, 20, м. Кременчук, Україна, 39600, Вищий державний навчальний заклад «Українська медична стоматологічна академія», вул. Шевченка, 23, м. Полтава, Україна, 36011

E-mail: Kolombogd@mail.ru 